\title{
UDC 631.547.1:633.35:[631.811.98:620.3] \\ SEED GERMINATION OF PEA BY SEED TREATMENT WITH MO NANOPARTICLES
}

L. M. HONCHAR, candidate of agriculture sciences, Associate Professor

\author{
B. M. MAZURENKO, assistant \\ O. V. PONOMARENKO, PhD student
}

National university of life and environmental sciences of Ukraine

E-mail: honchar@nubip.edu.ua

https://doi.org/10.31548/dopovidi2020.04.014

Abstract. Article highlights the results of research of the effect of pre-sowing seed treatment with molybdenum nanoparticles solution on the process of germination of pea variety NS Moroz and determination of the optimal concentration of molybdenum solution, which has an maximal positive effect on growth processes during germination.

The research was conducted in the Educational-Scientific Laboratory Demonstration Collection Field of Crops of the Department of Plant Science of the National University of Life and Environmental Sciences of Ukraine. Field and laboratory experiments were performed according to proven methods. Germination energy, germination and measurements of biometric parameters were determined.

Water solution with molybdenum concentration of 1:100 provided the highest seed germination at the level of $99 \%$, which has a positive effect in cultivation of peas, so field germination should also increase. The solution with Mo concentration of 1:10 had a positive effect on the length of the embryonic root of pea. It increased in length by $1.9 \mathrm{~cm}$ compare to control variant. Highest raw mass was formed by the treatment with Mo solution in concentration 1:100. This variant increased raw mass in stem by $0.06 \mathrm{~g}$ and $0.24 \mathrm{~g}$ in root system compare to control.

Key words: pea, Mo nanoparticles, seed treatment, stem, root, raw mass, colloidal solution

Actuality. Interest to legume cultivation grows in Ukraine nowadays. Pea is an important and popular legume crop in Ukraine. Main advantage of pea cultivation is ability to form high and stable yields in a short growing season. Growth and development are one of the most important agrobiological features of crops, which reflects a certain interaction of the plant genotype with a set of technological techniques and agro- climatic resources of the growing region. Sowing material is the basis of crop productivity, which provides $40-45 \%$ in the realization of biological potential, while cultivation technology provides 30-35 \%, and fertilizers - only $20 \%$. Plant density is necessary point for the formation of high yields of peas, which is reaches by establishing the appropriate seeding rate according weather and soil conditions. 
Гончар Л. М., Мазуренко Б. О., Пономаренко О. В.

Precipitation deficit was observed in Ukraine in March-April in recent years, so provoked continuous air drought that connected with soil drought in south of Ukraine. The longest and most severe rainfall deficit has been observed in southern Ukraine since last summer, so agrometeorological conditions for crop growth and development have been assessed as close to critical. Seedlings was liquefaction and delayed in development, crops were in a depressed state, because there was a deficit of available moisture in many fields. Pea plants can cover these nitrogen requirements due to seed inoculation and development of nodule bacteria in favourable conditions peas. Symbiotic nitrogen fixation processes can be significantly limited by insufficient moisture or low level of soil aeration $[1,2]$.

Main indicator of seed quality is the laboratory seed germination, that affects the field germination, which impact on yield [3]. There are a lot of method to improve laboratory and field seed germination nowadays, but each variety has an individual sensitivity to them [4].

Analysis last research and publications. Pea plants need the optimal ratio of moisture, heat, and nutrients since seed germination. Peas need a lot of moisture, especially during germination. This is $100-110 \%$ of water by seed weight, transpiration coefficient of $400-600$

Pre-sowing seed treatment with different materials can have a positive effect on seed germination and vegetation plants [5-9]. Plant productivity is improved by increasing the number of pods, seeds, seed weight per plant, and seed yield. Chemical, biological, physical factors influencing the condition of seeds to stimulate physiological processes of germination and development have different principles of action [8]. Pre-sowing seed treatments with solutions of nanometals help to increase crop yields to $20-35 \%$. In addition, there is an increase in the adaptation of plants to stressors during the growing season and improve the quality of agricultural products. Nanometals affect plants at the cellular level, increase the efficiency of processes in plants and participate in the formation of micronutrient balance $[9,10]$. The study of the positive properties of nanometals is carried out simultaneously with the detection of negative effects and prevention of risks from their use [11].

Aim of our research was to identify factors that have an inhibitory effect on the growth processes of peas and to determine the optimal concentration of nanomoliblen and to establish early symptoms of the negative effects of colloidal molybdenum solution on plants.

Methods. Laboratory research was conducted in the Educational-Scientific Laboratory "Analytical research in plant science" of the Department of Plant Science of the National University of Life and Environmental Sciences of 
Гончар Л. М., Мазуренко Б. О., Пономаренко О. В. Ukraine. Objects of research are water solution of Mo-nanoparticles with different concentration. There are 5 variants: control without Monanoparticles, Mo solution 1:1, Mo solution 1:10, Mo solution 1:100, Mo solution 1:1000 was researched. Research was conducted on pea variety NS Moroz.

Effect of Mo-nanoparticles solutions on germination, germination energy, root and stem length, raw mass of seedlings was determined. Laboratory germination is determined according to DSTU 4138-2002 "Seeds of agricultural crops". Germination energy was determined on the $5^{\text {th }}$ day, germination on the $8^{\text {th }}$ day. Biometric measurements were performed on the $8^{\text {th }}$ day.

Results. Peas develop slowly at the beginning of the growing season, the root system is still poorly developed, and pre-sowing seed treatment with micronutrients is essential way to improve peas adaptivity. Requirements for nutrients in peas is highest in the early stages of development. Molybdenum plays an important role in the formation of high yields of peas. It improves nitrogen metabolism in plants, participates in protein formation, enhances photosynthesis and nitrogen fixation. Molybdenum becomes non- available in soil solution on acid soils ( $\mathrm{pH}$ <5.5), so foliar application is recommended. Availability of Mo in Mo-nanoparticles solution does not depend on soil $\mathrm{pH}$.

Concentration of molybdenum in the solution had a significant effect on laboratory seed germination and energy of germination of peas. Variant without Mo-nanoparticles solution was characterized by germination energy at $83 \%$, but molybdenum treatment increased to 86-90 \% depend on concentration. Water solution of molybdenum with concentration 1:100 provided highest germination energy at $90 \%$, but higher concentration had a lesser effect (fig. 1).

Laboratory germination of pea seeds was $92 \%$ in the control variant, but seed treatment by Mo-nanoparticles solution with a concentration 1: 100 increased germination to $99 \%$. Relation between germination and concentration of Mo-nanoparticles in water solution is non-linear. Most effective variant is seed treatment by Mo-nanoparticles solution with concentration 1:100, so increasing the concentration decrease germination and energy of germination in peas. It should be noted that Mo-nanoparticles solutions are toxic to nodule bacteria. 
Гончар Л. М., Мазуренко Б. О., Пономаренко О. В.

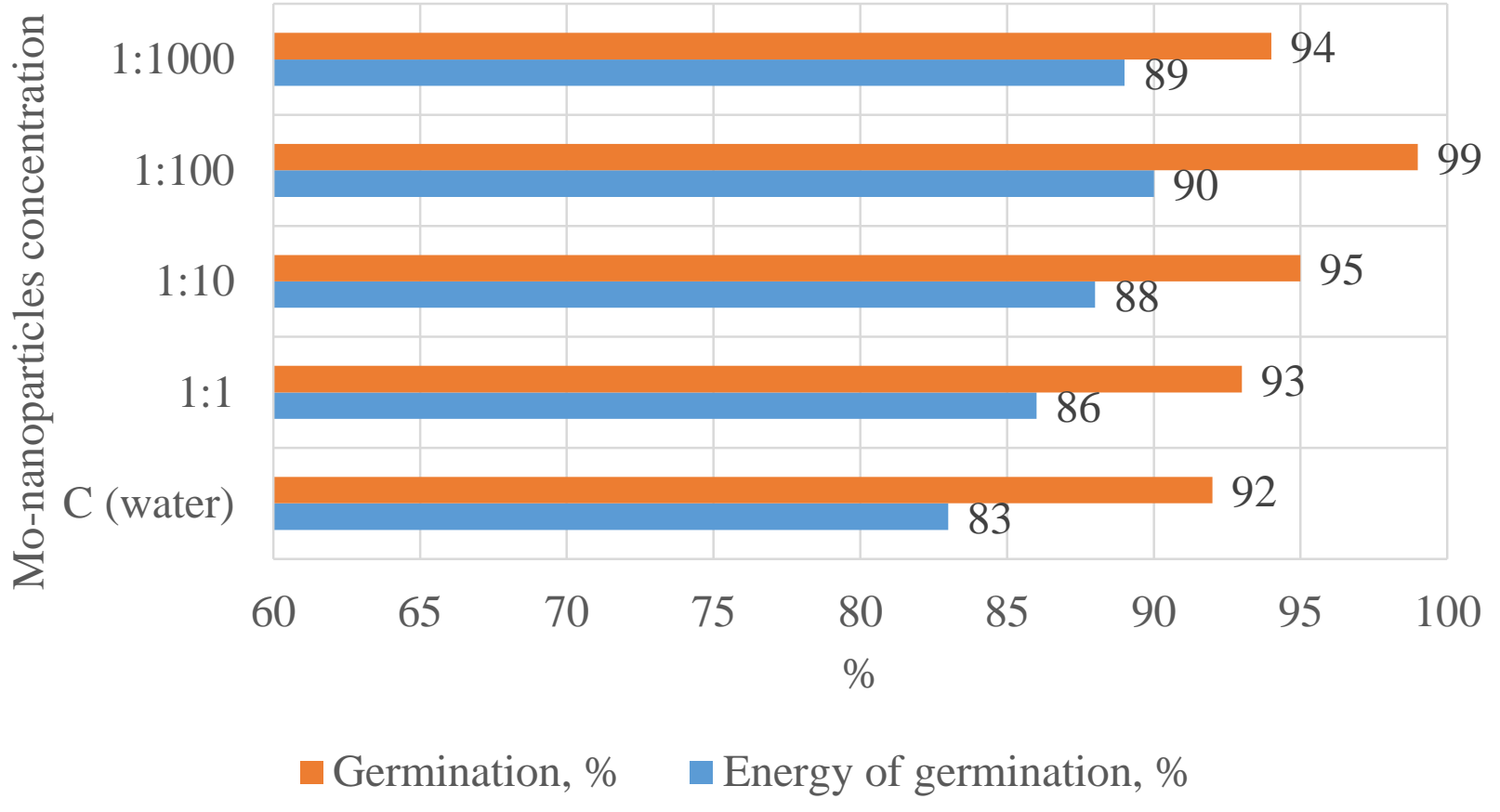

Fig. 1. Energy of germination and laboratory germination of pea depend on concentration of Mo-nanoparticles solution, \%

Seed treatment with Mo- ratio of 1:1.56; in variant with a nanoparticles solution influenced growth concentration of 1:10 it was 1:1.77; in a intensity and biometric parameters of pea variant with a concentration of 1:100 it seedlings, respectively, the ratio of stem was $1: 1.38$; in the variant with a to root in the control was $1: 1.71$. Seed concentration of $1: 1000$ was $1: 1.34$ treatment in concentration of 1:1 gives the (fig. 2).

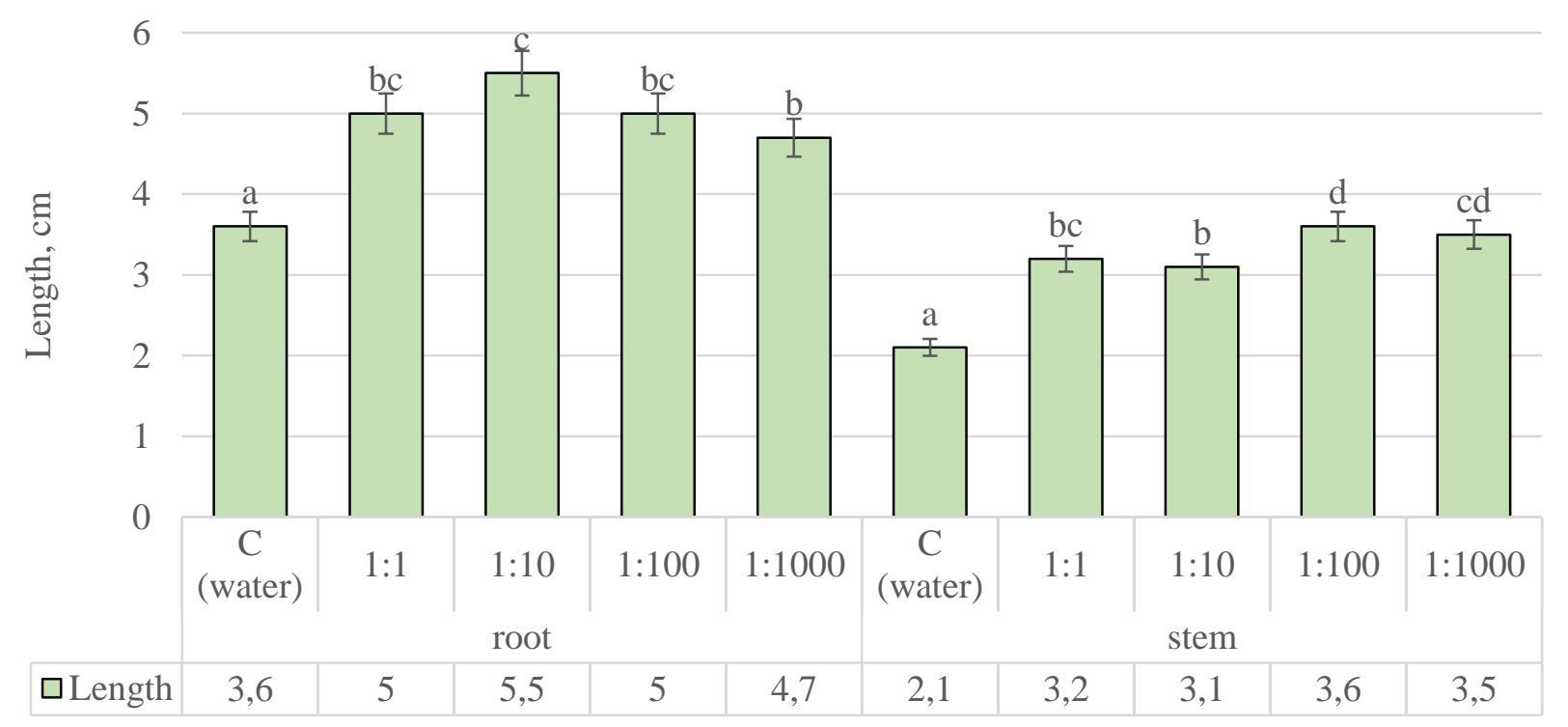

Different superscripts denote statistical significance at $\mathrm{p} \leq 0.05$

Fig. 2. Length of root and stem of peas depend on concentration of Monanoparticles solution, $\mathrm{cm}$ 
Research showed that the seed treatment with Mo-nanoparticles solution did not have an inhibitory effect in the early stages of growth, regardless of its concentration, as the length of the stem and root in the treated variants exceeded the control variant. It was found when analyzing the ratio of stem and root, the largest gap between them in the Mo2 variant with a subsequent decrease in concentration decreases to $1: 1.34 \pm 1.38$.

Raw mass of seedlings increased significantly regardless of the concentration of Mo-nanoparticles compared to control. Raw mass of roots was $0.43-0.52 \mathrm{~g}$ by treatment of Monanoparticles solution, and stem was 0.16-0.20 g (fig. 3).

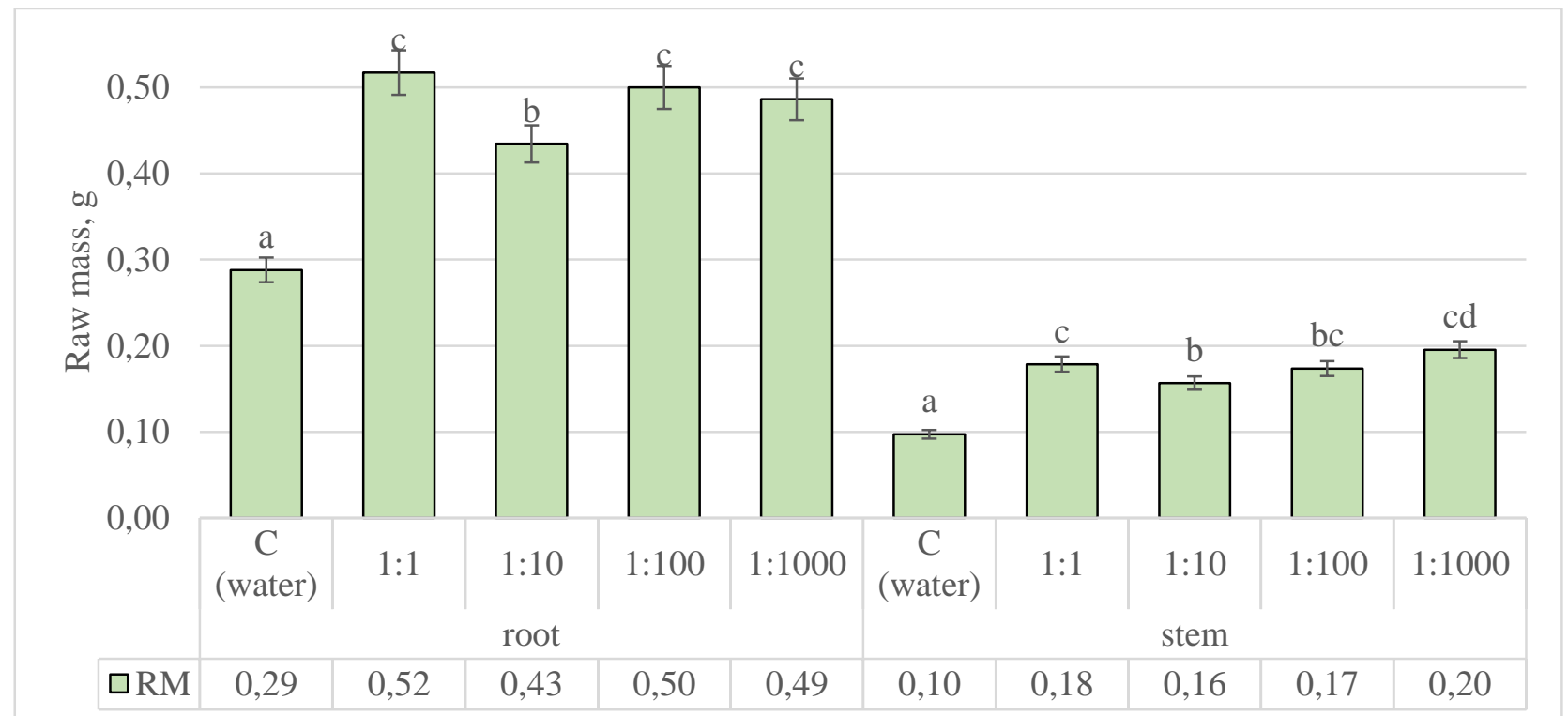

Figure 3. Raw mass of seedlings depends on concentration of Monanoparticles, $\mathrm{g}$

Positive effect on the linear growth of root system and stem was found. Seed treatment with Mo-nanoparticles solution had a positive effect on root growth in the initial stages of pea development. Greatest root length and raw mass were obtained at a concentration of Mo-nanoparticles solution 1:10. The positive effect of Monanoparticles solution concentrations of 1:100 and 1:1000 was also established, the obtained data exceed the control variant and require more detailed research.

Conclusions. Conducted research and analysis of obtain results have few key points:

1. Pre-sowing treatment by Mo-nanoparticles solution stimulates seed germination in peas. Seed treatment by solution in concentration 1:10 and less had a positive effect on seed germination and its energy. 
Гончар Л. М., Мазуренко Б. О., Пономаренко О. В.

2. Most effective concentration to give a maximum seed germination is 1:10 Mo-nanoparticles.

3. Seed treatment with Monanoparticles solution had a positive effect on root length, raw mass, and seedling length. Mo solution in

\section{Список використаних джерел}

1. Дашківська М. О., Сітнікова С. О., Шевчук О. А. Насіннєва продуктивність гороху за дії регуляторів росту рослин. In The 17 th International scientific and practical conference "Science, trends and perspectives》 (18-19 May, 2020). Tokyo, Japan, 2020. 432 p. ISBN-978-1-64871-420-7. P. 184.

2. Гончар Л. М., Пилипенко В. С. Польова схожість насіння та густота стояння рослин гороху посівного залежно від удобрення та інокуляції. Науковий журнал «Рослинництво та трунтознавство», 2017, (269), С. 30-36.

3. Kaiser B. N., Gridley K. L., Ngaire Brady J., Phillips T., Tyerman S. D. The role of molybdenum in agricultural plant production. Annals of botany, 2005, 96(5), 745-754. https://doi.org/10.1093/aob/mci226

4. Taran N., Batsmanova L., Kosyk O. and other. Colloidal Nanomolybdenum Influence upon the Antioxidative Reaction of Chickpea Plants (Cicer arietinum L.). Nanoscale Res Lett, 11, 2016. 476. https://doi.org/10.1186/s11671-016-1690-4.

5. Shcherbakova E. N., Shcherbakov A. V., Andronov E. E. and other. Combined preseed treatment with microbial inoculants and Mo nanoparticles changes composition of root exudates and rhizosphere microbiome structure of chickpea (Cicer arietinum L.) plants. Symbiosis, 2017. 73(1), 57-69. https://doi.org/10.1007/s13199-016-0472-1

6. Shcherbakova E. N., Rots P. Y., Mulina S. A. and other Inoculation technology for legumes based on alginate encapsulation. Agronomy Research.Vol. 16, Issue 5, 2018, P. 2156-2168.

http://dx.doi.org/10.15159/ar.18.186

7. Cruz I., Bashan Y., HernàndezCarmona G., De-Bashan L.E. Biological deterioration of alginate beads containing immobilized microalgae and bacteria during concentration 1:10 increased root length on $1.9 \mathrm{~cm}$ and stem length on $1.0 \mathrm{~cm}$ compare to control. Its effect on the raw mass was manifested in an increase of $0.06 \mathrm{~g}$ of stem and $0.24 \mathrm{~g}$ of root compared to control.

tertiary wastewater treatment. Applied Microbiology and Biotechnology, 2013. 97 (22), pp. 9847-9858. https://doi.org/10.1007/s00253-013-4703-6

8. Taran N., Batsmanova L., Konotop Y., Okanenko A. Redistribution of elements of metals in plant tissues under treatment by nonionic colloidal solution of biogenic metal nanoparticles. Nanoscale research letters, 2014, 9(1), 1-4. https://doi.org/10.1186/1556276X-9-354

9. Taran N.Y., Gonchar O.M., Lopatko K.G. and other. The effect of colloidal solution of molybdenum nanoparticles on the microbial composition in rhizosphere of Cicer arietinum L. Nanoscale Res Lett, 2014. 9, 289. https://doi.org/10.1186/1556-276X-9-289

10. Lopatko K. G., Melnichuk M. D., Aftandilyants Y. G. and other. Obtaining of metallic nanoparticles by plasma-erosion electrical discharges in liquid mediums for biological application. Annals of Warsaw University of Life Sciences-SGGW. Agriculture, 2013. (61 Agric. Forest Eng.).

11. Каленська С.М., Тонха О.Л., Лопатько К.Г., Афтанділянц С.Г. Маточний колоїдний розчин металів: апт. 38459. Україна: В01J 13/00. заявл. 12.08.08; опубл. 12.01.09, Бюл. № 1.8 с.

\section{References}

1. Dashkivska, M. O. Sitnikova, Ye. O. \& Shevchuk, O. A. (2020). Nasinnieva Produktyvnist Horokhu Za Dii Rehuliatoriv Rostu Roslyn. In The 17 th International scientific and practical conference «Science, trends and perspectives» (18-19 May, 2020). Tokyo, Japan. 432 p. ISBN-978-1-64871-4207. 184.

2. Honchar, L. M., Pylypenko, V. S. (2017). Polova skhozhist nasinnia ta hustota stoiannia roslyn horokhu posivnoho zalezhno vid udobrennia ta inokuliatsii. Naukovyi zhurnal «Roslynnytstvo ta gruntoznavstvo». 
Гончар Л. М., Мазуренко Б. О., Пономаренко О. В. (269). 30-36.

3. Kaiser, B. N., Gridley, K. L., Ngaire Brady, J., Phillips, T., \& Tyerman, S. D. (2005). The role of molybdenum in agricultural plant production. Annals of botany, 96(5), 745-754.

https://doi.org/10.1093/aob/mci226

4. Taran, N., Batsmanova, L., Kosyk, O., Smirnov, O., Kovalenko, M., Honchar L. \& Okanenko A. (2016). Colloidal Nanomolybdenum Influence upon the Antioxidative Reaction of Chickpea Plants (Cicer arietinum L.). Nanoscale Research Letters, 11, 476. https://doi.org/10.1186/s11671-016-1690-4.

5. Shcherbakova E. N., Shcherbakov A. V., Andronov E. E. Gonchar, L.N., Kalenskaya, S.M. \& Chebotar, V.K. (2017) Combined pre-seed treatment with microbial inoculants and Mo nanoparticles changes composition of root exudates and rhizosphere microbiome structure of chickpea (Cicer arietinum L.) plants. Symbiosis. 73(1), 57-69. https://doi.org/10.1007/s13199-016-0472-1

6. Shcherbakova, E. N., Rots, P. Y., Mulina, S. A. Gonchar, L.N., Yahina, L.M., Lactionov, Yu.V. \& Chebotar, V.K. (2018) Inoculation technology for legumes based on alginate encapsulation. Agronomy Research, 16(5), 2156-2168.

http://dx.doi.org/10.15159/ar.18.186

7. Cruz, I., Bashan Y., HernàndezCarmona, G. \& De-Bashan, L.E. (2013)
Biological deterioration of alginate beads containing immobilized microalgae and bacteria during tertiary wastewater treatment. Applied Microbiology and Biotechnology, 97 (22), 9847-9858. https://doi.org/10.1007/s00253-013-4703-6

8. Taran, N., Batsmanova, L., Konotop, Y., \& Okanenko, A. (2014). Redistribution of elements of metals in plant tissues under treatment by non-ionic colloidal solution of biogenic metal nanoparticles. Nanoscale research letters, 9(1), 1-4. https://doi.org/10.1186/1556-276X-9-354

9. Taran, N.Y., Gonchar, O.M., Lopatko, K.G. Batsmanova, L.M., Patyka, M.V. \& Volkogon, M.V. (2014) The effect of colloidal solution of molybdenum nanoparticles on the microbial composition in rhizosphere of Cicer arietinum L. Nanoscale Research Letters, 9, 289. https://doi.org/10.1186/1556-276X-9-289

10. Lopatko, K. G., Melnichuk, M. D., Aftandilyants, Y. G., Gonchar, E. N., Boretskij, V. F., Veklich, A. N., ... \& Trach, V. V. (2013). Obtaining of metallic nanoparticles by plasma-erosion electrical discharges in liquid mediums for biological application. Annals of Warsaw University of Life SciencesSGGW. Agriculture, (61 Agric. Forest Eng.).

11. Kalenska, S.M., Tonkha, O.L., Lopatko, K.H. \& Aftandiliants, Ye.H. (2009) Matochnyi koloidnyi rozchyn metaliv: apt. 38459. Ukraina: B01J 13/00. zaiavl. 12.08.08; opubl. 12.01.09, Biul. № 1. 8 .

\section{ПРОЦЕС ПРОРОСТАННЯ НАСІННЯ ГОРОХУ ЗА ОБРОБКИ НАСІННЯ НАНОРОЗЧИНОМ МОЛІБДЕНУ Л. М. Гончар, Б. О. Мазуренко, О. В. Пономаренко}

Анотація. У статті висвітлено результати досліджень щуодо впливу передпосівної обробки насіння нанорозчином молібдену на процес проростання гороху сорту НС Мороз та визначення оптимальної концентрації наномолібдену, яка має ефективний вплив на ростові прощеси під час проростання.

Дослідження проводили на дослідному полі навчально-наукової лабораторії "Демонстрачійне колекиійне поле сільськогосподарських культур» Національного університету біоресурсів $і$ природокористування України. Польові та лабораторні досліди виконувалися згідно апробованих методик. Проводили визначення енергії проростання, схожості та заміри біометричних показників. 
Гончар Л. М., Мазуренко Б. О., Пономаренко О. В.

Конценттрація молібдену 1:100 найвищу схожість насіння $99 \%$, щз має позитивний вплив у подальшому вирошувані гороху. Так, як із збільшення лабораторної схожсості зростає і польова, що веде до формування оптимальної густоти гороху. Найбільша довжина кореня була за конщентрацією Мо 1:10 збільшилась на 1,9 см порівняно з контролем та незначне збільшення довжини стебла на 1,0 см. Встановлено, що найбільша вегетативна маса була сформована за конщентрації 1:10 колоїдного розчину молібдену, збільшення надземної маси на 0,06 г та кореневої системи на 0,24 г порівняно з контролем.

Ключові слова: горох, наномолібден, обробка насіння, стебло, коріння, сира маса, колоїдний розчин 